\title{
The end of body composition methodology research?
}

Citation for published version (APA):

Heymsfield, S. B., Pietrobelli, A., Wang, Z., \& Saris, W. H. (2005). The end of body composition methodology research? Current Opinion in Clinical Nutrition and Metabolic Care, 8(6), 591-594. https://doi.org/10.1097/01.mco.0000171151.43410.a5

Document status and date:

Published: 01/01/2005

DOI:

10.1097/01.mco.0000171151.43410.a5

Document Version:

Publisher's PDF, also known as Version of record

\section{Please check the document version of this publication:}

- A submitted manuscript is the version of the article upon submission and before peer-review. There can be important differences between the submitted version and the official published version of record.

People interested in the research are advised to contact the author for the final version of the publication, or visit the DOI to the publisher's website.

- The final author version and the galley proof are versions of the publication after peer review.

- The final published version features the final layout of the paper including the volume, issue and page numbers.

Link to publication

\footnotetext{
General rights rights.

- You may freely distribute the URL identifying the publication in the public portal. please follow below link for the End User Agreement:

www.umlib.nl/taverne-license

Take down policy

If you believe that this document breaches copyright please contact us at:

repository@maastrichtuniversity.nl

providing details and we will investigate your claim.
}

Copyright and moral rights for the publications made accessible in the public portal are retained by the authors and/or other copyright owners and it is a condition of accessing publications that users recognise and abide by the legal requirements associated with these

- Users may download and print one copy of any publication from the public portal for the purpose of private study or research.

- You may not further distribute the material or use it for any profit-making activity or commercial gain

If the publication is distributed under the terms of Article $25 \mathrm{fa}$ of the Dutch Copyright Act, indicated by the "Taverne" license above, 


\section{EDITORIAL REVIEW}

\section{The end of body composition methodology research? Steven B. Heymsfield ${ }^{\mathrm{a}}$, Angelo Pietrobelli ${ }^{\mathrm{b}}$, ZiMian Wang ${ }^{\mathrm{c}}$ and Wim H.M. Saris ${ }^{\mathrm{d}}$}

\section{Purpose of review}

Over one century of research has led to methods for measuring all major body components at the atomic, molecular, cellular, and tissue-system levels. These remarkable developments have fueled a rapid and sustained increase in 'body composition' biological findings and related publications. Other than small, incremental improvements in available methods, is there no longer a need for developing new body composition methods? This review examines the question: are we approaching the 'end' of body composition methodology research?

\section{Recent findings}

Emerging and rapidly growing areas outside of 'traditional' body composition research are highlighting the need for new and innovative method development. Recently introduced technologies such as positron emission tomography and functional magnetic resonance imaging extend 'mass' estimates to corresponding 'function' and physiology in humans. Although all major components are now measurable in humans, large gaps remain when considering factors such as radiation exposure, invasiveness, static versus dynamic measurements, and laboratory versus clinic and field assessments.

\section{Summary}

The end of the first phase of body composition method development has now arrived: all major components are measurable in vivo. The accessibility of these methods is stimulating rapid advances in biological knowledge surrounding human body composition from in utero to old age. Sustaining advances in new body composition method development will require extending the boundaries of the field as it now exists.

\section{Keywords}

five-level model, metabolism, nutritional assessment

Curr Opin Clin Nutr Metab Care 8:591 -594. C 2005 Lippincott Williams \& Wilkins

${ }^{\mathrm{a}}$ Merck \& Co., Rahway, New Jersey, USA, ${ }^{\mathrm{b}}$ Pediatric Unit, Verona University Medical School, Verona, Italy, 'New York Obesity Research Center, St. Luke'sRoosevelt Hospital, Columbia University College of Physicians and Surgeons, New York, USA and ${ }^{\mathrm{d}}$ Nutrition and Toxicology Research Institute, NUTRIM, University of Maastricht, The Netherlands

Correspondence to Steven B. Heymsfield, MD, Executive Director, Clinical Research, Metabolism, RY34A, 126 E. Lincoln Avenue, P.O. Box 2000, Rahway, NJ 07065-0900, USA

Tel: +1 732594 4448; fax: +1 732594 3750

e-mail: Steven_Heymsfield@Merck.Com

Current Opinion in Clinical Nutrition and Metabolic Care 2005, 8:591-594

(C) 2005 Lippincott Williams \& Wilkins $1363-1950$
In his classic book End of Science, John Horgan describes the rational idea that one day all scientific knowledge will be in hand [1]. Some fields have already reached maturity and progress in these areas is slow and findings are incremental. Others are new and exploding with activity. Like life itself, scientific disciplines are born, grow, mature, and potentially reach their logical 'end'.

The assessment of body composition in animals and humans in vivo is an area of scientific research that overlaps with many different fields and disciplines. Nevertheless, there is a central core of scientists who meet on a regular basis (website: http://www.bc2005. soton.ac.uk) and whose primary focus is the development of methods for quantifying the different body compartments. Several journals now have entire sections devoted to body composition research and a new journal, the International Journal of Body Composition Research (website: http://www.ijbcr.com), is solely focused on methods and findings in the area. There are several multi-author textbooks on body composition methodology and findings [2-7], and a second edition of one [7] was released in the past several months. A search of PubMed with the term 'body composition' shows a striking rise over time in the yearly rate of total publications (Fig. 1) with no abatement in sight. But can we rest assured that the end of the 'methodology' area, specifically, is not approaching in the near future? There is a good reason to ask this question.

Body composition methodology is an area of investigation dedicated to the study and application of methods used to quantify body components from atomic to whole body levels. The methodology area of body composition research extends back several hundred years, but modern developments were initiated in the past century.

Early investigators had practical considerations in mind, for example, finding a means by which to non-destructively establish the oil content of fish [8]. A novel method was devised by which the fish specific gravity was established and oil quantified using a 'two-component' model. The two-component model qualitatively assumed that one component was oil with a low specific gravity and the second component was the remaining tissue with a higher specific gravity. Accordingly, specific gravity became a measure of fish oil content. During the mid 1940s the fish oil technique was refined and extended by Albert Behnke 
Figure 1. Yearly publications observed using the term 'body composition' on PubMed

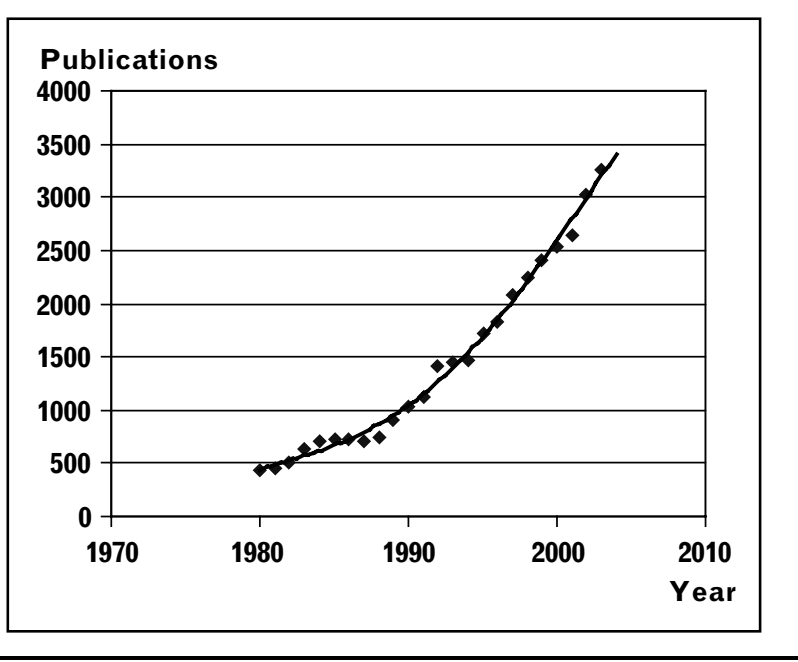

and his colleagues [9]. Behnke developed an underwater weighing system that included adjustment of specific gravity for residual air trapped in the lungs. Behnke and his colleagues also advanced a quantitative twocompartment human model consisting of fat and fat-free mass (often referred to as lean body mass), each with assumed stable densities. Siri [10,11] and other later investigators refined these density estimates such that in humans fat is now assumed to have a density of $0.9 \mathrm{~g} /$ $\mathrm{cm}^{3}$ and fat-free mass a density of $1.1 \mathrm{~g} / \mathrm{cm}^{3}$ at body temperature. Assuming these two stable densities and provided with the subject's measured density by underwater weighing, one can then compute the percentage of body weight as fat. The two-compartment model was later extended to three (water, fat, and residual mass) and four-compartment (water, fat, mineral, and residual mass) models with the addition of measures such as total body water and bone mineral [12]. Thus, when combined with other introduced methods such as in-vivo neutron activation analysis, all components at the 'molecular level' of body composition (Fig. 2) became measurable by the 1980s.

This specific methodology evolution and other similar parallel developments [7] is striking as over the past several decades the entire body composition compartment 'map', in addition to molecular level components, has been filled in (Fig. 2) [13]. The map shows the major body compartments at the four relevant levels, atomic, molecular, cellular, and tissue-system/organ. All of the compartments shown in Fig. 2 can now be measured in clinical and research settings with varying levels of accuracy and precision. For skeletal muscle, major muscles can be individually measured and not just the total body compartment. Similarly, many selected regions within the adipose tissue compartment are now recognized and can be accurately measured in vivo. Some complexities remain, such as how to measure very young subjects or even subjects in utero; and the 'super-obese'. Even these areas are getting increasing scrutiny and are examined in this issue (Friedman, Bernstein, Shen and Das). Refined methods are being reported on a regular basis, such as the introduction of air displacement plethysmography, reviewed here by Fields, as an accurate and practical alternative to Behnke's original underwater weighing technique now in use for over five decades [9]. Thus, the possibility exists that body composition methodology research may be reaching an incremental stage and that the 'explosion' in publications, now more than 3000 per year, is due to application of the available methods to improve understanding of biological processes. A key development is that many of the newer

Figure 2. The first four of five body composition levels

Adapted with permission [13]

\begin{tabular}{|c|c|c|c|}
\hline $\mathbf{N}, \mathbf{C a}, \mathbf{P}, \mathrm{K}, \mathrm{Na}, \mathrm{Cl}$ & Lipid & \multirow{3}{*}{ Adipocytes } & Adipose \\
\hline H & \multirow[b]{2}{*}{ Water } & & Tissue \\
\hline C & & & $\begin{array}{c}\text { Skeletal } \\
\text { Muscle }\end{array}$ \\
\hline \multirow[t]{2}{*}{0} & Proteins & $\begin{array}{l}\text { Extracellular } \\
\text { Fluid }\end{array}$ & $\begin{array}{l}\text { Visceral } \\
\text { Organs \& } \\
\text { Residual }\end{array}$ \\
\hline & Minerals & $\begin{array}{l}\text { Extracellular } \\
\text { Solids }\end{array}$ & Skeleton \\
\hline Atomic & Molecular & Cellular & Tissue-System \\
\hline
\end{tabular}


methods are increasingly available to a wide spectrum of investigators and not to only a few isolated 'experts'.

Is the end of body composition methodology research in sight? As Horgan reflects [1], is the best research behind us? Or are there critical gaps that remain unfilled? Some components are still quite difficult to measure, such as total body protein. Several strategies for quantifying protein mass are available, but the classical reference method, in-vivo neutron activation analysis, is installed and functional at only one or two centers in the world. Some methods, such as bioimpedance analysis for estimating body fat, are not very reliable for individual subject evaluations, particularly for detecting small fat mass changes over short time periods. Thus, there is a clear and finite need for improving on some of the already available methods. New technologies are required to make these methodology gains rather than additional refinements in older methods.

Rather than proclaim an end-in-sight for body composition method research, we might reconsider the component map presented in Fig. 2. This classical treatment of body composition compartments could be viewed as the 'first phase' of research in the area instead of the definitive boundaries of the field. Other, new and more in-depth maps can be created and methods sought. For example, why not develop methods designed to measure beyond total body protein to skeletal muscle contractile proteins or liver protein; even total liver collagen protein? The capability of measuring this next level of components would lead to a myriad of new research opportunities. Rather than 'body cell mass', why not attempt to accurately quantify liver cell mass, liver mitochondrial mass, or even pancreatic beta-cell mass? International efforts are already underway searching for means to measure these compartments that are central to disease processes, although much of the research is outside what might be considered 'classical' body composition investigation. Bridging these discipline gaps is critical because the knowledge gained by transcending traditional scientific boundaries may be substantial. At a cellular level we have seen the development of transcriptomics, proteomics, and more recently, also metabolomics, leading to the holistic approach of system biology. Classical body composition research might thus be viewed as the foundation of a field that has yet linked to these 'omics' technologies to emerge as a powerful research tool for all biological and medical sciences.

The classical body composition map as outlined in Fig. 2 is also concerned largely with measuring the mass or volume of structures and not their 'functions'. Since biological 'malfunctions' are at the heart of disease processes, body composition measurements often take the back seat to more proximal functional estimates. Fully
Figure 3. Measures of tissue/organ mass and function followed over time

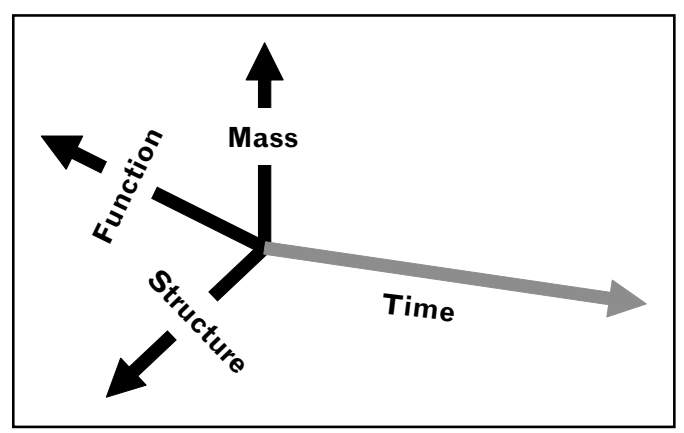

Such measures are required for characterizing biological and pathological processes in animals and humans.

characterizing physiological and disease processes in vivo, however, ideally captures changes in mass, structure/ shape, and function over time (Fig. 3). Imagine being able to accurately measure both pancreatic $\beta$-cell mass and insulin secretion over time, particularly in response to various lifestyle and pharmacologic interventions. This is not a science-fiction dream, but a finite current goal of many research groups. Cardiac function, structure, and mass are now measurable using gated magnetic resonance imaging and myocardial oxygen consumption can be estimated using methods as such as oxygen-15 positron emission tomography (PET). Newer methods such as PET and functional magnetic resonace imaging and spectroscopy are aligning measures of mass, function, and metabolism.

Examining the wide potential scope of body composition methodology research gives rise to other new unexplored or only partially studied research pathways. The methods for estimating the mass of components in Fig. 2 can be organized, for example, into those that are appropriate for measuring total body versus regional, invasive versus non-invasive, radiation versus non-radiation, and static versus dynamic. The resulting body composition maps now have many open cells with methods awaiting either improvement or new development.

\section{Conclusion}

Boundless opportunities are available to not only develop new and powerful body composition measurement methods, but for greatly expanding the scope of biological knowledge. Traditional body composition methodology research, however, has not yet fully expanded into rapidly growing fields and bridges need to be built that join divergent and separate lines of scientific inquiry. Otherwise, the field of body composition methodology research is in danger of losing its brightest minds and reaching a finite end as predicted for some scientific areas by Horgan [1]. Alternatively, extending the field's 
boundaries to new research areas and aligning with other developing fields could lead to a sustained, even invigorated, scientific discipline devoted to body composition method development.

\section{References}

1 Horgan J. End of science: facing the limits of knowledge in the twilight of the scientific age. New York: Little, Brown, and Co; 1997.

2 Moore FD, Oleson KH, McMurray JD, et al. The body cell mass and its supporting environment. Philadelphia: WB Sanders; 1963.

3 Forbes GB. Human body composition: growth, aging, nutrition, and activity. New York: Springer-Verlag; 1987.

4 Davies PSW, Cole TJ, editors. Body composition techniques in health and disease. Cambridge: Cambridge University Press; 1995.

5 Ellis $\mathrm{KJ}$, Eastman JD, editors. Human body composition: in vivo methods, models, and assessment. New York: Plenum; 1993.
6 Speakman JR, editor. Body composition analysis of animals: a handbook of non-destructive methods. Cambridge: Cambridge University Press; 2001.

7 Heymsfield SB, Lohman TG, editors, Human body composition. 2nd ed. Champaign: Human Kinetics; 2005.

8 Heymsfield SB, Wang ZM. Measurement of total body fat by underwater weighing: new insights and uses for an old method. J Nutr 1993; 9:472-473.

9 Behnke AR, Feen BG, Welham WC. The specific gravity of healthy men. JAMA 1942; 118:495-498.

10 Siri WE. The gross composition of the body. In: Tobias CA, Lawrence JH, editors. Advances in biological and medical physics. New York: Academic; 1956. pp. $239-280$.

11 Siri WE. Body composition from fluid spaces and density: analysis of methods. In: Brozek J, Henschel A, editors. Techniques for measuring body composition. Washington DC: National Academy of Sciences National Research Council; 1961. pp. 223-244.

12 Heymsfield SB, Wang ZM, Withers R. Multicomponent molecular level models of body composition analysis. In: Roche A, Heymsfield SB, Lohman TG, editors, Human body composition. Champaign: Human Kinetics; 1996. 129-147.

13 Wang ZM, Pierson RN Jr, Heymsfield SB. The five level model: a new approach to organizing body composition research. Am J Clin Nutr 1992; $56: 19-28$ 